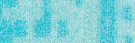

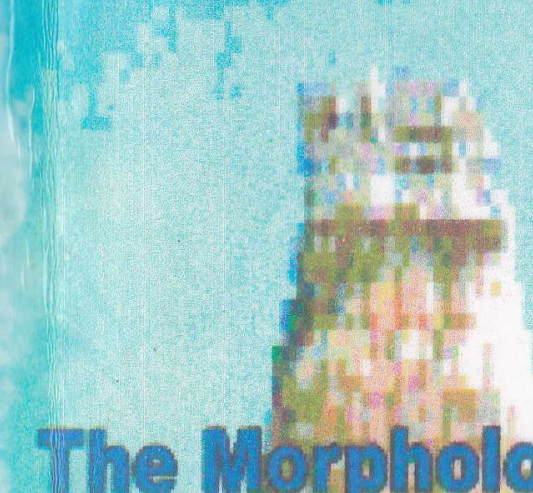

$\int\left(x-x^{2}=y^{2}\right.$

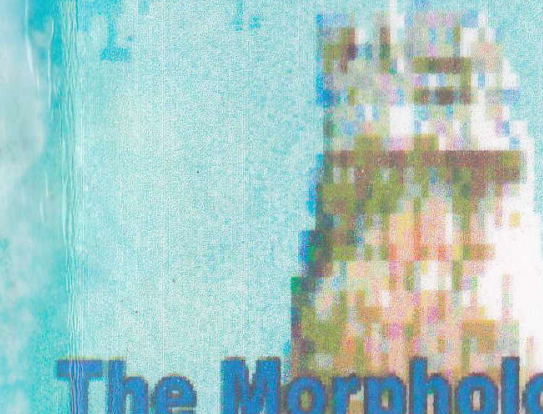

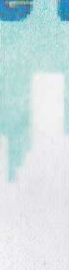

it The Regency of

sithergen

Gau Province Indor

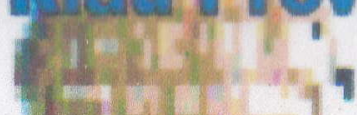

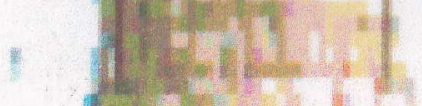

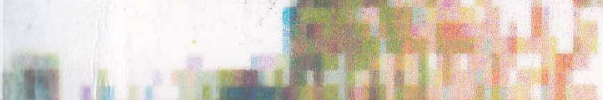

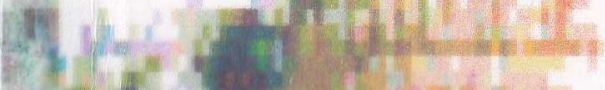

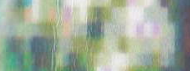
$\operatorname{lin}^{2}(x)=$

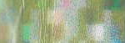

1) $3=2$

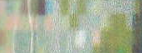

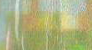

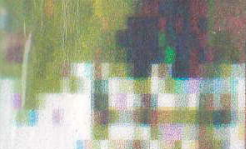

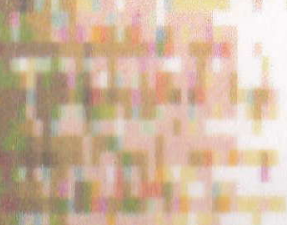

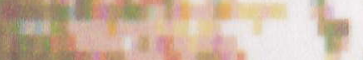

2.

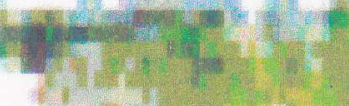

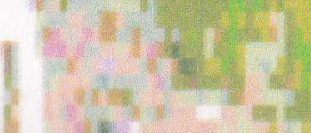

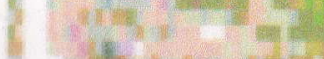

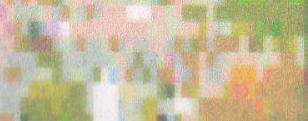

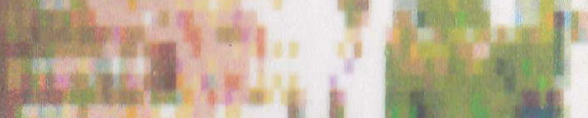

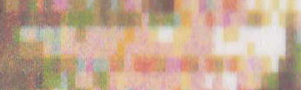

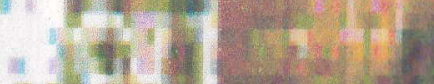

(1) 
SENO H.PUTRA Drs.,M.Pd.,Ph.d

\section{THF, MORPHOLOGY OF RENGAT} DIALECT IN THE REGENCY OF INHU, RIAU PROVINCE, INDONESIA

UNRI PRESS

2006 
1. Barangsiapa dengan sengaja dan tanpa hak menggunakan atau memperbanyak suatu cintaan atau memberi izin untuk itu, dipidana penjara paling lama 7 (tujuh) tahun dan atau denda paling banyak Rp. 100.000 .000 (Seratus Juta Rupiah)

2. Barangsiapa dengan sengaja menyiarkan, memamerkan, mengedarkan, atau menjual kepada umum suatu ciptaan atau barang hasil pelanggaran hak cipta sebagaimana dimaksud dalam ayat (1), dipidana dengan pidana penjara paling lama 5 (lima) tahun atau denda paling banyak Rp. 50.000 .000 (Lima Puluh Juta).

Perpustakaan Nasional : katalog dalam terbita (KTD)

THE MORPHOLOGY OF RENGAT DIALECT IN THE REGENCY OF INHU, RIAU PROVINCE, INDONESIA

\section{Oleh:}

\section{SENO H.PUTRA Drs.,M.Pd.,Ph.d}

\section{Penerbit UNRI Press}

\section{ISBN : 979-792-058-5}

Hak Cipta dilindungi Undang-Undang.

Dilarang mengutip atâl memiperbanyak daiam bentuk Apapun, bila tidak ada izin tertulis daripenerbit

Design Cover/Lay Out : Oksep Adhayanto

Terbit November 2006

\section{PREFACE}

This book the third publishment, the first in 1998 and the second in 2004. This book is as report and summary of my master degree's thesis. It is designed to be a book derives from a study which has been investigated in the field from January to March in 1997, as well as examined by 5 Professors in Agustust 1997 at IKIP, Malang.

It has also been a ward of scienific study for the election of model lecturers in June 1998 at Padang. Consequently, since this research concerned to a linguistic study, and it is the first step found for Rengat Dialect it self, it is urgent to introduce this book as a study result to the readers, particularly students and scholars interested in the field of linguistic studies.

It, in addition, can be reading sources, or reference for those who will research fenomena relate to Linguistics. Since the local languanges are rare invesiugdeci, espcuiäly is Nìau Provirice, this bock besides can be a document for the local government, it must also be maintained from extination.

Lastiy, suggestions and eritiesme from the readers are accepted for the future impovement.

Pekanbaru, November 23, 2005 


\section{Contents}

Introduction
A. Background of the Problem (1-3)
B. Coniext of the Problem (2)
C. Statements of the Problem (3)
D. Objeotives of the Research (3)
E. Significance of the Rasearoh (4)
F. Assumptions of the Researoh (4)
G. Limitation of the Problems (5)
H. Definition of Key Torms ( 5 )

\section{Methodology and Research Procedure}

A. Research Design (6)

B. Location of the Research (7)

C. Population and Sampling Procedure (7)

D. Research Instruments (8)

E. Data Sources of the Research ( 9 )

F. Techniques of Collecting Data ( $\theta$ )

C. Technique of Data Analysis (10)

\section{Results}

A. Morphological Processes of Rengat Dialect (12)

1. Prefixation: $\{\mathrm{N}-\} \rightarrow / \eta / 1, / \mathrm{m}-1, \mathrm{n}-1,1 \mathrm{n}-1$ (12)

2. Prefixes [b 3 -] and [t2.] (12)

3. Suffixation (14)

4. Confixation (15)

5. Reduplication (16) 
6. Compounding (16)

B. Morphophonological Process of Rengat Dialect (16)

1. Assimilation (17)

2. Dissimilation (19)

Summary, Conclusion, and Suggestions
A. Summary (20)
B. Conclusion (23)
C. Suggestions (25)

References

\section{THE MORPHOLOGY OF RENGAT DIALECT IN THE} REGENCY OF INHU, RIAU PROVINCE, INDONEDIA

Senohimalaputra, The Morphology of Rengat Dialect in the Regency of Inhu, Riau Province, Indonesia

Key words: Morphology, Morphophcnolcgy, Rangat dialact

\section{INTRODUCTION}

\section{A. Background of the Problem}

The Indonesian 1945 Constitution and the 1993 National Guidelines state that the local languages are the olements of our national oultural heritage. These languages are very important as the foundation of the national language and we must maintain them from extinction. One of which is Riau Language or the Malay language of Riau.

The Malay language of Riau is an indigeneous tongue of approximately $3,300,000$ population who reside in two areas, for example, the archipelago and the mainland. However, this language has two geographical varieties, that is the archipelago Malay and the mainland Malay. The two varieties are slightly distinct, and each is considered as a dialect.

The language of Riau has been used by the people of Riau as a lingua franca since the Kingdom of johor and Riau Lingga (archipelago) existed, and other neighboring countries, like Malaysia, Singapore, and Brunei also use this language (Dahlan, 1991). It is also the origin of Bahasa 
Indonesia, the language proclaimed by the first Congress of the Indonesian Youth in 1928 in Jalsarta as the unifying language, and it is our rational language (Badudu, 1993:3).

The Malay language of Riau, actually, comprises several dialects, $\theta . g$., the archipelago of Tanjung Pinang regency consists of 16 distriots, even though, the dialeots used in the speeoh community are mostly the same as one another. However, Bengkalis posseases 12 districts and has its own dialects; while similarly the mainland, suoh as Kampar, Pekanbaru, Indragiri Hulu, and Indragiri Hilir also have their own dialects. The differences and similarities of these dialects that can be found in each area are phonological, morphological, and syntaotioal features.

Although the Malay language of Riau has a number of dialeots, this research is only focused on the dialeot of Rengat. This dialeot was chosen in this research because it is unique, partioularly in its morphology, and it also has never been investigated. It is derived from the standard of the Malay language which is very semilan to the dialeots of ine archipeiago, but is rather different phonologisaily, lexically, and syntactically from those in the mainland. In other wcrds, although Rengat district is thy capital city of Indragiri Hulu ragenoy which ombaraces nine disiriots, its dialect is different from those in Kuantan Hulu, Kuanian Hilir, Basran, Cerenti, Sirsgingi, Peranap, eto.

Linguistically and sociclinguistioally, the Malay" languaga of Riau has only been investigated in a few studies, for example, (Dahlan, 1983 and 1991) on the dialeot of Kampar, the dialect of Siak, and the dialeots of several coastal areas of Riau, such as Bengkalis, Bagan Siapi-Api, Selat Panjang, Tanjung Pinang, Tanjung Batu, Dumai, and Tembilahan, as well as (Hamidy, 1995) the dialect of Taluk
Kuantan areas of Indragiri Hulu regenoy. However, most of these studies were limited by the phonological aspeot. This research investigates the morphologioal aspect of Rengat dialect in the regenoy of Inhu, Riau Provinoe.

\section{B. Context of the Problem}

Although a fow studies of Riau dialect have been conducted (Dahlan, 1983;1991, Hamià, 1990̈; and Suwardi, 1985), most of them have focused on phonology. No studies have been done on the morphology of Rengat dialect. In this research, therefore, two major problems are investigated. The morphology and morphophonology of Rengat Dialect in the Regency of Inhu, Riau Province.

\section{Statements of the Problems}

The problems of this research are:

(1) What kinds of the morphological processes are found in Rengat Dialeot in the Regency of Inhu, Riau Provinoe?

(2) What kinds of the morphophonological processes of Rengat Dialect in the Regency of Inhu, Riau Province?

\section{Objectives of the Research}

The objectives of the research are as follows:

(1) generally, to describe the morphological and morphophonological processes of Rengat Dialect in the Regency of Inhu, Riau Province. 
(2) speoifically, to disoover the morphologioal and morphophonological processes of Rengat Dialect in the Regenoy of Inhu, Riau Province in the aspeots of prefixation, suffixation, confixation, reduplication, compounding, assimilation, and dissimilation.

\section{E. Significance of the Research}

The proposed study is hoped to:

(1) produce the descriptive morphology of Rengat Dialect in the regency of Inhu, Riau Province.

(2) furnish information for those who are interested to conduct research concerning itself with the dialects of Riau Province.

(3) develop the teaching of local content course, such as Rengat Dialect itself and English at the Elementary level.

(4) contribute to the Department of Education and Culture, specifically, Indragiri Hulu regsncy, and, genorally, Riau Province for the consideration as development of curriculum of local content courss.

\section{F. Assumptions of the Kesearon}

This study is conducted on the basis of the following assumptions:

(1) The morphology of Rergat dialect has different systems of phonology and morphology from those in the mainland of Indragiri Hulu Regancy.

(2) The morphology of Rergat dialeot has similar systems of phonology and synyax to those in the arohipelago.

(3) Rengat dialeot has its own systems of phonology which consists of vowels, consosnants, suprasegmental phonemes, and diphtongs.

(4) Rengat dialeot has its own morphology which consists of words and morfhemes.

\section{G. Limitation of the Problems}

Since the region of Riau Province is broad and contains its own dialects, this stiudy is onnducted with the purpose of describing the morphology of Rengat Dialsct in the Regency of Inhu, Riau Province. To be specific, the limitations of the problems are stated as follows:

(1) To find out the morphological processes in the aspects of prefixation, suffixation, reduplication, and compounding in Rengat Dialect in the Regency of Inhu, Riau Province.

(2) To find out the morphophonological processes in the aspects of assimilation and dissimilation in Rengat Dialect in the Regency of Inhu, Riau Province.

\section{H. Definition of Key Terms}

Morphology is the process of forming words or morphemes in a language and how they ocour. 
Morphology of Rengat dialect refers to the system of morphemes and the process of word formation based on Rengat dialeot

Descriptive morphology refers to the description about the process of the construction of morphology and morphophonology based on the dialect of Rengat.

Dialect refers to a part of a language which is commonly used by local poople, or refers to a language spoken by groups of people in certain area. Its differences and similarities of the systems of a language can be found in morphology, phonology, and syntax.

Rengat is the name of one of nine districts which lies in the Indragiri Hulu Regency and it is also the name of the capital city of this regency.

\section{METHODOLCGY AND RESEARCH PROCEDURE}

\section{A. Research Design}

The design of this research is descriptive qualitative. This was based on the process of investigation involving aseription and interpretation which could be assigned without manipulating variables. In other words, this research was conducted as cosmical as possible in the field, and it described the data found incrinsically.

This research was conducted in the field, it used the descriptive method, and the investigator went directly into the field by applying certain facets of research, for example, (1) observation, and 120 listening, recording, and henceforth writing about the dialect of Rengat distriot. Doing so, it provided the invostigator with secure and solid data.

\section{B Location of the Research}

This research was carried out in Rengat district of Inhu, Riau Province, Indonesia. Since Indragiri Hulu ragency embraces 9 districts and it has its own dialocts, this restarch was aimed at Rerigat district. There wore thre日 principal motives for choosing it to become a place of this research. They are, first, the dialect used by tha spe日ch community is not influenced by the other dialects. Second, its major population and culture are Malay. Lastiy, its region and number of the population size is not large.

\section{Population and Sampling Procedure}

The target population of this research was all the indigenous people of Rengat district. Although the number of the population of this district is not large, it is difficult for the investigator to retain the entire population. So, this research is confined by one subject as a sample of this research, or as a representative of the target population. One subject which is used in this research is to collect the linguistic corpus data only.

There were also other reasons for electing one subject to collect the linguistic corpus data. First, it was easy for the investigator to collect the data. Second, it did not take much time and money. Bogdan (1983), thus, atates that in qualitative research, such as descriptive study, in 
which a researcher oan a detailed examination of one particular setting, or one single subject. In addition to this the oharaoteristios of the subject (informant) for linguistio corpus data of this research is posited in the table below.

$\begin{array}{cl}\text { Distriot } & \text { Rengat } \\ \text { Kind of Sex } & \text { Male } \\ \text { The number ofSubject } & 1 \\ \text { Age } & 40\end{array}$

Other characteristics of the subject in this research are (1) he was an indigenous person, and he has his own culture, (2) he uses or speaks that dialest in his daily life and society, (3) he masters or knows that dialect, and (4) he is a normal person, talkative, and he talks freoly and naturally.

Samarin (1967) states that a good informant should have the following characteristics: (1) he must be good speaker of the language; he must have its own cuiture; (3) he must be a good story teller and should not have lived away from the community for s6veral years; he can talk freoly and naturally on a wicie range of subjocis relovant to his own culture; and (5) he is an elderly person, approximately 30 yoars old, often makes more available informants than younger people.

\section{Research Instruments}

There are four informants amployed in this research. First, the informant was used to obtain the data sources about morphology and morphophonology. Secono, the investigator himself who conducted from the informant, the investigator was also invoived in the field. Third, questionnaire was used to know the characteristics of the informant nimself. Finally, the tape-recorder was used to record the informant's speech in the field.

\section{E Data Sources of the Research}

As mentioned in the previous chapter one subject can be a sample of this research. Therefore, there were four sources that the invastigator used in this research. They are: (1) data sources which wors based on linguistis corpus of morphology such as prefixation, suffiration, confixation, reduplication, and compounding in Rengat district in the Regency of Inhu, Riau Province, Indonesia; (2) data sources which were based on linguistic corpus of morphophonemics such as assimilation and dissimilation in Rengat dialect in the regency of Inhu, Riau Province, Indonesia; (3) data sources which were based on the interviow used to elecit the linguistic corpus from the informant's spe日ch which was relevant to his own experience; and (4) the questionnaire which was used to obtain information concerning the characteristics of the informant himself.

\section{F Techniques of Collecting Data}

In this research, the elicitation technique was used to collect the data. Samarin (1967) states that elicitation can be used as a technique for corpus collection and language analysis. In addition to this, the motives to elect this technique in this research were (1) the utterances 
obtained in elicitation are short, (2) the elioitation is motivated towards analysis of some aspeots of the linguistio system, and (3) elicitating is defined by the intimate human relations established between the investigator and his informant that affect the nature of the data cbtained and their interpretation (Samarin, 1967).

The elicitation technique has several procedures, one of which can be applied in this research is analytical olicitation.

Analytioal Elioitation is a technique whioh oan be oonsidered a probing device, oomparable in some ways to open-ended questions in interviewing. For example, oan you you tell me about your self? So, in this research the investigator applied such a technique to acoumulate informant's utteranoes while speaking about his own experienoe.

\section{G Technique of Data Analysis}

The techniques of data analysis which are used in this research are descriptive. They describe the linguistio corpus whish relates to the morpholozioal and morphophonological features of the informant's speeshes of Rengat dialect. T'he dssuriptions are anlysed as follows: (1) having recorded and collected the data from the informant, the investigator ciassified them in two olasses, that is, one belonged to morphology and the other to morphophonemios. The data obtained from the informant's speoches were transcripted into a text and then these data conoerned with the aspeots of morphology, suoh as affixation, confixation, reduplioation, compounding, assimilation, and discimilation.; (2) having olassified the data, the investigator listed and wrote them out to make 2 desoription (transcription) based on the problems of the researoh. The description based on the phonemic and morphophonemic featuras of Rengat dialout; (3) having listed and written the data, the investigator ohooked and tested them to make the accuracy. The data which had been written into a taxt were resxamiried to se日 whether the forms of the morphological and morphophonolozical processes of Fengat dialeot were really acourate; (4) having checked and tested the data, tho investigator sought another informant to rechsok the data transoribed into 2 text. This informant was one who mastered and knew that diaiect, and he was also a good informant. This informant was to prove whether the data were really relevant to dialect of Rengat or not. The data were also oonoerned with the phonemic and morphophonemic features of Rengat dialeot; and (5) repetitions of the oassettes of the informant's speeches were also required to look after the reliability and validity of the data. This way, specifioally, was to find out the exact aspects of the morphology itself, for example, the phonemin and morphophonemis features of Rengat dialsot.

\section{RESULTS}

This chapter discusses the results of the research of Rengat dialeot in the regency of Inhu, Riau Province. The data analysis was based on the problems of the research. First, they refer to the morphological processes whioh onoompass prefixation, suffixation, confixation, roduplioation, and compounding, and second to the 
morphophonologioal processes including assimilation and dissimilation. They are described as follows:

\section{A. Morphological Processes of Rengat Dialect}

\section{Prefixation: $\{\mathrm{N}-\} \rightarrow|\mathrm{m}-1,| \mathrm{m}-1, \ln -1,|\mathrm{t}-|$}

In forming prefixation in Rengat dialect, in which prefix $\{\mathbb{N}-\}$ changes to become phonemes $|\mathrm{m}-1, \ln -1,| \mathrm{n}-1$, and in/ when it is followed by roots beginning with vowels and certain consonants. Prefix $\{N-\}$ changes to become $/ \eta /$ when it is followed by roots beginning with vowels such as $/ \mathrm{a} /,|d|$, liv, $|\mathrm{J}|, \mid \mathrm{W} /$ and consonants $|\mathrm{g}|, \mid \mathrm{k}^{\prime}$, and $N$. For example, phoneme [a] in roots lankat/; [e]>/eda/; [i] $>$ /ik $D$ t;

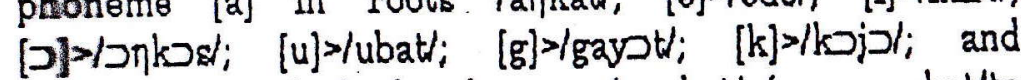
[l] $>$ DDpasl, in which they become /nankat/ (mengangkat/to lift); Ineda (mengedar/to revolve); Inikot/ (mengikut/to

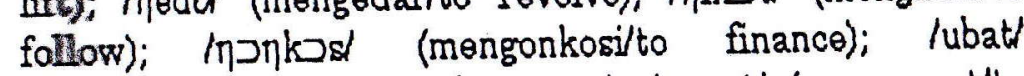
(mengobati/to ireat a kick person); (gayst) (menggayut/to hang); ikojal (mengejarito run after); and Mopas (melepasito releasa) in Rengat dialect. Phoneme[k] is dropped in forming prefix and (1] ratains and there is an additional vowel [O] barwenn [N-] and phoneme [1] in the process.

Prefix $\{\mathrm{N}-\}$ becomes $/ \mathrm{m}-\mathrm{f}$ when it is followed by roots beginning with consonant $\mathrm{B} /$. For example, [b] in B Bli become /mbJil/ (membeli/to buiy); prefix \{iN-\} becomes /n-t when it is followed by roots beginning with certain consonants $|d|,|d|,|j|$, and $|t|$. For example, phoneme; [c] $>/$ cailkJV; [d]>/dorjJ/; [j]>ljJmpJt/; and / J Jlal/, in which they become incantoly (mencangkol/to hoe); indonjl (mendengar/to hear); /njJmpJt/ (menjemput/to piok up); and Inslall (menolatelto refuse). In the prodess the [t] is dolated if it is prefixed with $(\mathbb{N}-\}$. In addition, prefix $\{\mathbb{N}-\}$ becomes / II- if it is followed by the roots beginning with consonants [8]. This consonant is deleted if it is prefixed with \{N-\}. For example, /sJmpIt becomes lompIt' (menyempit/to narrow).

\section{Prefixes [ba] and [ta- $]+$ Roote}

$$
\text { ค. Prefix [bo-j }
$$

Prefixas [ba-] and [ta-] maan to do something as in its roots, and [bo-] is associated with the roots beginning with consonants $[b],[0],[d],[g],[j],[k],[l],[m],[n],[p],[s]$, [t], and [w]. Prefix [bo-] in Rengat dialoct is also similar to the Indonesian [ber-] in the prooess of forming prefixation. For example, /baju/>/babaju/ (berbaju/wearing clothes); loanda/ $/$ bocanda/(borcanda/joking);/damai/>/badamai/(borda mai/makingpeace);/ganti/ >/baganti/(berganti/substituting);

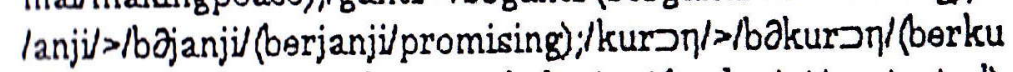
rung/shuttingdown);/lanjat/>/balanj $\supset t /$ (borlanjut/protacted); /main/>//bamain/(bormain/play);/napas/>/banapas/(Bernapas/

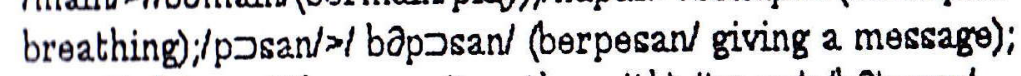
/sam $/>/$ b dsama (borsama/togethsrwith);/tつmu/>/batsmul (bertemu/me日ting);and/wali/>/bowali/(berwali/inhering).

\section{b. Prefix [ta- ]}

In Rengat, dialact prefix [to-] means to do something unintentionally. It is followed by the roots 
beginning with consonants $[\mathrm{b}],[\mathrm{c}],[\mathrm{d}],[\mathrm{d}],[\mathrm{b}],[\mathrm{k}],[\mathrm{l}]$, $[\mathrm{m}],[\mathrm{n}],[\mathrm{p}],[\mathrm{s}],[\mathrm{t}],[\mathrm{w}]$, [y], and [z]. Prefix [ta-] in Rengat dialoct is also similar to the Indonesian [ter-] in the process of forming prefixation. To be clear, the examples which are described below based on the certain consonants above. For example, lb $2 y \supset \eta / x \mid t a b \supset y \supset \eta l$ (terboyong/to be shifted from); loampa?>ltacampa?l (tercampak/to be

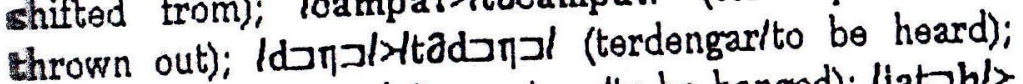

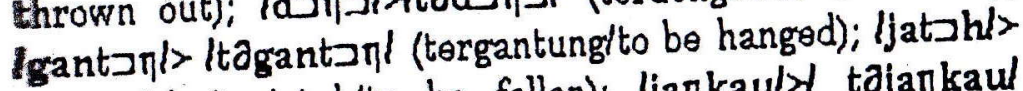
Itajatzhl (terjatuh/to be fallon); ljamkauly tajankaul (terjangkaultobe reashed); lkosanl/ttak $\supset$ sanl (terkesanito beimpressed);/Lpas/ / /taLpas (terlepas/tobereleased); Im

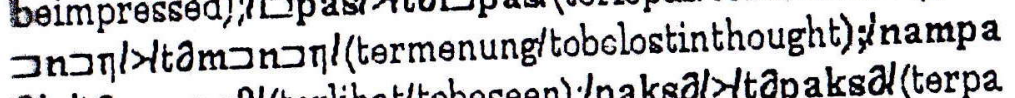
2/N/tanampa?/(terlihat/tobeseen); /paksal//tapaksal(terpa

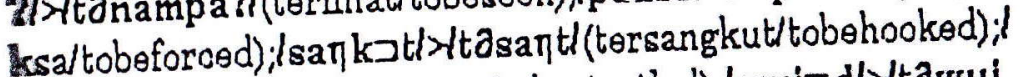

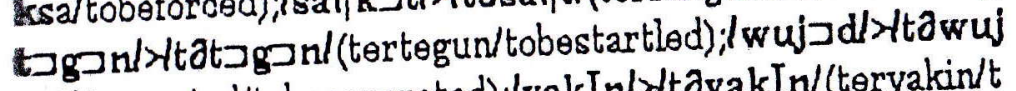
בd/(terwujud/tobeconoreted);/yakIn//ttayakIn/(teryakin/t obelieved);andlziarah//ttaziarah/ (terziarah/to be visited sacred placo).

\section{Suffixation}

The suffixation found in Rengat dialect was only suffix [-an]. This suffix is aiso similar to tha Indonesian [kan], and it is used to staie request or order as in its own roots. For example, suffix [-an] in Rengat dialect cocurs when it is precoded by a word ending in the vowel [I] like i b $\supset l l+[$-an $\}]=$ /b [1], [t], [h], and [k], such as ambil > lambi-anl (ambilkan/take); /buat $>$ /buat-an/ (buatkan/make); jatsh $>$ /jat $\supset$ h-anl (jatuhkan/fall down); and masa? > /masa?-an/ (masakan/cook), otc.

\section{Confixation}

There are thre日 kinds of confixation which axist in Rengat dialoct. They are to 2 -....anl, Idi-...-anl, and lpa....anl. These confixations mean to do something as in their own roots. For axample, Confix \{b2...-an\} can be inserted by the roots ending in the vowel [D] and consonants [h], [m], [?], [l], and [t]. They are in vowels like ldual > lbadua-anl (barduasnibeing as togather); and lsamal > lodaamz-anl (barsamaan/to be togattier); and consonants, such as /labכhl > hôlab $\supset$ h-an' (berlabuh-an/anchoring); Imalam/>/hómalamani(termalaman'spəndingnight);/pJga $\eta />/ b \partial p \supset$ gan-ani (berpegangan/hoiding on another): IsambJtl > lbo sambJt-anl (bersambutan' wolcoming); ljual/>/bojualani(berjualan/solling); and/sandI $\mid />/ b d s a n d I$ $\eta$-anl (borsandingan/sitting next to).

Confix \{di-...-an\} occurs in passive forms. It can be inserted by the roots ending in the vowels [D], [I] and connonants [?], $[\mathrm{h}],[\mathrm{p}]$, and [t]. This prefix means to do somathing as in its own roots. For axample, in vowels, like ladal > /diada-anl (diadakan/to be hold); /b Jlil >/di b anl (dibolikan/to bo bought), atg., and in consonants, such as /d $\supset$ ndan/>ldid $\supset$ ndan-anl (didendangkan/to be sung); /d כ kat/)/di d Jkat-anl (didekatkan/to be closed, atc. Confix [po-...-an], finally, in Rengat dialect can bo inserted by the roots ending in the consonants $[\mathrm{h}],[\eta],[\mathrm{n}]$, and $[\mathrm{t}]$. For axamplo,lnikahl/panikah-an/(pornikahan/marriagement); |silat/> Ip dsilat-an/ (persilatan/systems of self-defence);

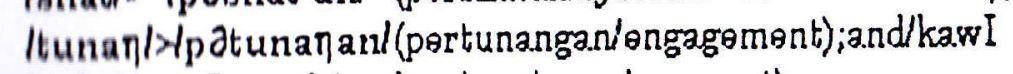
n/ $/$ /pokawIn-and (pørka.winan/marriagement). 


\section{Reduplication}

Reduplication in Rengat dialect encompasses some forms derived from their own roots. In other words, reduplication of Reneat dialect can be constructed through out the ways of its own roots and pronunciations. Its forms are complete reduplication of its roots, reduplication with affixes, and reduplication with the change of phoneme. For example, in complete reduplication of its roots, /kirois/kird- kird (kira-kira/about), etc. Reduplication

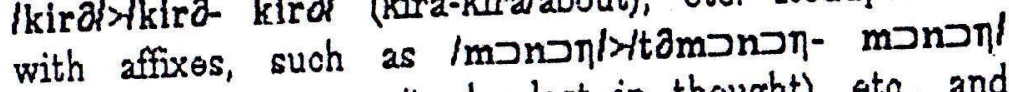
(termenung-termenung/to be lost in thought), eto., and Reduplication with the shange of phonemes like Igra?/1g pra?-goril/ (gsrak-gerik/movements), etc. All the reduplications above are derived from their own roots.

\section{Compounding}

Compounding of Rengat dialect comprises some forms. Thoy are $\mathrm{N} 1+\mathrm{N} 2 ; \mathrm{V} 1+\mathrm{N} 1 ; \mathrm{N} 1+\mathrm{Aaj} ;$ and AditN1. For example, N1+N2> lbiji timon! (biji timun/cucunibor seed), etc., $\mathrm{V} 1+\mathrm{Nl}>$ lcבcah inail (cocah inai/touching henna), etc., N1+Adjolb kuning/yellow rice), stc; and AditNlofmalam axi/ (malam hari/night), etc.

\section{B. Morphophonological Process of Rengat Dialect}

The morphophonolegical processes of Rengat dialect inciude assimilation and dissimilation. Assimilation includes regressive assimilation, progressive assimilation, addition of phoneme, and delation of phoneme. Dissimilation encloses substitutional process of phoneme and insertion.

\section{Assimilation}

Assimilation process which is found in Rengat dialeot can be categorized to become some forme. They are regressive assimilation, prograssive assimilation, assimilation with an addition phoneme, and assimilation with a phoneme deletion. For example, regressive assimilation, in Rengat dialeci comprises scme forms. The (N-) becomes hormoganios consonanits im-l, int, and intl. They are $(\mathrm{N}-\} \rightarrow / \mathrm{m}-\mathrm{i}$ if it is followed by roots beginning with phoneme [b], like ib دlail >im blail (membelai/to caross), otc., $\{\mathrm{N}-\} \rightarrow$ int if it is followed by roots beginning with phoneme [c] and [j], such as icaral/>inosrall (mencerailto divorce), etc. $[\mathrm{N}-\mathrm{\}} \rightarrow \mathrm{i} / \mathrm{n}-\mathrm{f}$ it is followed, by the roots beginning with vowels, such as [a], [e], [I], [J], [u], and consonants [s], [l], and [s]. For example, [N-]+Root > lankat/dinankat) (mengangkat/to lift); ledars inedd (mengedar/to revolve); /ikat/inikatl (mengikut/to follow);

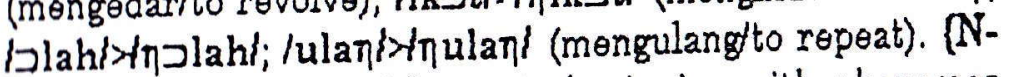
\}$\rightarrow \mid \eta-1$ if it is followed by roots beginning with phonemes [s] and [1], for example, /gayst/>ingayat/ (menggayut/to hang), and /liat/>/naliat/ (molihat/to $s \in \partial) .(N-\} \rightarrow-/ N /$ if it is followed by roots beginning with consonant [s]. This consonant is dropped if it is formed to become prefixation, for example, /sambat/>/nambJt/ (menyambut/to welcome), atc. 
a. Progressive Assimilation

Prograssive assimilation in Rengat dialect only consists of one form. A consonant [n] which is attached at the end of a. morpheme of /dian/ changes to become the sound [?] when it is followed by another morpheme beginning with a. consonant [d], for exampla, /dian danau/s/dia? danau/s/durian danau/.

\section{b. Additional Process of Phoneme}

Assimilation with additional prooess of phonemes in Rengat dialect comprise only one form, that is, addition of a phoneme $[\theta]$ after vowel, in which the oertain morphemes of Rengat dialect which are ended by the vowels [e] and [I] can be added by phoneme [e]. Semantically, phoneme $[\theta]$ means as "nya" or dia (hisher). For example, loara-e/>lcara-nya/the wayl; /bantaie/>/bantai/pukul-nya/the fight; $\mid s \partial m u \partial-\theta />/$ semua-nya/its

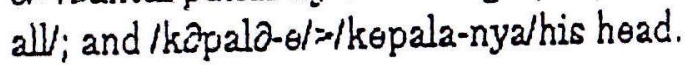

\section{c. Doletion of A Phaneme}

Assimilation with deletion of a phonems in Rengat dialoct is caused by the combination of some phonemes, such as [h] and $[\mathrm{k}]$ in their roots, so that in realization those phonemes are deleted, and they become their nasalization. For example, phoneme [h] in the process the $[h]$ is drupped when it is formed in prefixation and suffixation, such as nabsht $\rightarrow$ |bolabJ-anl (berlabuhan/anchoring); and phoneme $[k]$ is dropped when it is formed in affixation, for example, Imasuld $\rightarrow$ /maso-and (memasulianito entor)., aic.

\section{Dissimliation}

There are two linds of dissimilation found in Rengat dialect, such as substitutional process of a phoneme and insertion.

\section{a. Substitutional Process of Phoneme}

Substitutional process of phoneme in Rerigat dialect oncurs in the process of changing a phoneme from its roots in reduplication. For example, Mracaubaiau/>/kacau-balau/ (chaostic); na-? paح?>Mauk pauks (a variety of side dishes); /tungan-langan/ (head over heols); and /rJcai d Jrai/s/recai derai/(broken in many grains). From these examples, thre are substitutional process of phonemes, in which phonemes [k] becomes [b] in the words of "kacau balau", phonemes [1] becomes [p] in the words of "la of "rscai drai".

\section{b. Insertion}

The insertion of phonemes [w] and [y] in Rengat dialect occurs in certain roats or morphemes which are ended by the vowels [u] and [I] in forming affixation. For example, /pulau/s/kzpulauwan/ (kepulauan/island); and loari/>/pдncariyan/(pencarian/livelihood). 
The two examples above show that the insertion of phoneme [w] ocours in morpheme of pulau" and phoneme [y] in morpheme of "oari".

\section{SUMMARY, CONCLUSION, AND SUGGESTIONS}

This chapter presents a brief summary, conclusion, and suggestions. The summary and conolusion explain the morphological and morphophonological processes of forming words in Rengat dialect. Suggestions explain the suggestions of the research itself.

\section{A. Summary}

This summary presents two parts of the research: first, the morphological processes which include affixation, reduplication, and compounding, and second, the morphophonological processes which include assimilation and dissimilation.

\section{Tha Morphoiugical Processes of Rengat Dialect}

Baced on the results, this research found several forms of morphological aspects. They ars (1) affixation which included prefixes, suffixes, and confixes; (2) reduplication which included complete reduplication, reduplication with the change of a phoneme, and reduplication with affixes; and (3) compounding which included Noun1+Noun2, Verbl+Noun1, NounitAdj, and AdjtNounl. The summary is described as follows: a. Affixation of Rengat dialoct encompassed prefixation [N]$:[\eta-],[n-],[m-],[n-j$, and prefixation [ba-j and [ta-]. Suffixation was found only [-an] and confixation consisted of three forms: (1) [di-...-an], (2) [b2-...-an], and [p2...an].This affixation was to find out the process of forming words or morphemes to become other morphemes which were derived from their own roots.

b. Reduplioation was found in thres forms: (1) complete reduplication, (2) reduplication with the ohange of a phoneme, and (3) reduplication with affixss. Complete reduplication was conctrunted by ropeating all parts of tho roots becoming twice with the same meanings. For example. in the word of /pantan/> /pantan- pant 2 /. Reduplication with the change of a phoreme was constructed by changing one of its phonemes to another one derived from its roots. For example, in the word of

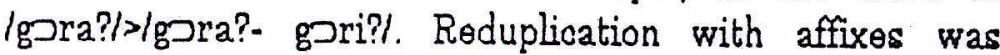
oomplete reduplication together with an addition of affixes.

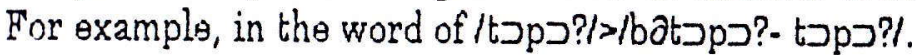

c. Compounding was found in four forms: (1) Nounl + Noun2, (2) Verb1 + Noun1, (3) Noun1 + Adjeotive, and (4): Adjective + Noun1. The process of forming this compounding was also similar to ones of the Indonesian, in which the first part of the morpheme explained the second one. For example, (1) /rumah kaluagol (N1+N2), (2)/panjat pinan/ (VI+N1), (3) /bכras kunIn/ (N1+Adj), and (4) /malam aril (adj+N1). 
2. The Morphophonological Processes of Rengat Dialect

The morphophonological processes of Rengat dialect encompassed assimilation and dissimilation. Assimilation included regressive assimilation, progressive assimilation, addition of a phoneme, and deletion of a phoneme. Dissimilation enclosed substitutional process of a phoneme and insertion. The summary is described as follows:

a. Assimilation of Rengat dialect consisted of four forms: (1) regressive assimilation, (2) progressive assimilation, (3) addition of a phoneme, and (4) deletion of a phoneme. Regressive assimilation is the process of changing a phoneme infront of its environment. Roots or morphemes of Rengat dialect which were begun in consosnants [b], $[c]$,

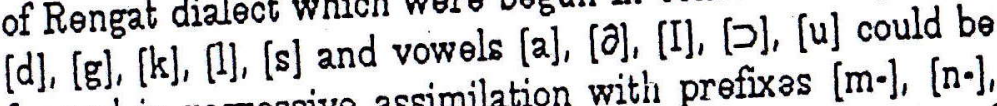
formed in regressive assimilation with prefixas $[\mathrm{m}-]_{1},[\mathrm{n}-]_{\text {, }}$ $[\eta \cdot]$, and [n-]. Progressive assimilation is the process of changing a phoneme behind a sound of its anvironment. Tha process of regressive assimilation occured in a morpheme ending in a consunant $[n]$. In the procsss the [n] which was foliowed by another morpheme beginning with a consonant [d] changed to become a sound of [?] in pronouncing. For example: durian danau $\rightarrow$ Idia?danaul. Addition of $a$ phoneme is the process of adding a phoneme in a morpheme. Addition of a phoneme in Rengat dialect occured in a morpheme ending in vowels [e] and [I]. In the process the morpheme which was added by a phoneme $[\theta]$ reîrred to personal or possessive pronouns. For example:

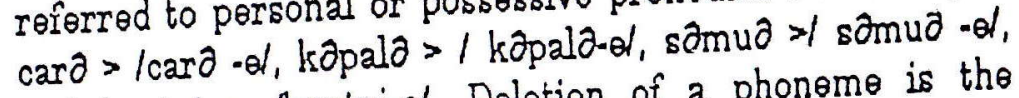
and tantai > Bantai-el. Doletion of a phoneme is the process of dropping a phoneme in a morpheme. Consonants $[h]$ and [k] whinh were attached to a morpheme of Eengat dialect were deleted in forming prefixation and suffixation.

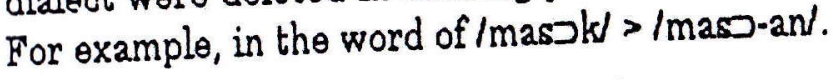

b. Dissimilation of Rengat dialoct was found in two forms: (1) substitutional process of a phonema and (2) insertion. Substitutional process of a phoneme is the process of substituting of a phoneme to another one in a morpheme. The conaonants [ $[\mathrm{r}],[\mathrm{lj},[\mathrm{r}],[\mathrm{t}]$ which were attached to osrtain roots or morphemes of Rengat dialoot could be substituted into those in [b], [d], [p], [i] in reduplication. For example, $[\mathrm{k}]>[\mathrm{b}]$ in /kacau balaul, $[\mathrm{l}]>[\mathrm{p}]$ in $/ \mathrm{la}>$ ?

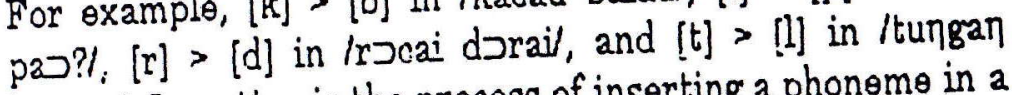
langanl. Insertion is the process of inserting a phoneme in a morpheme. Certain morphemes of Rengat dialect which were ended by the vowels [I] and [u] could be inserted by the phonemes $[w]$ and $[y]$ in forming affixation. For example, in the words of /pulaul $>/$ kepulauwan and loari/ $>$ Ipencariyan/.

\section{B. Conclusion}

Thre are five findings drawn from the study which will be presented in the following conclusions.

\section{(1) The Morphological Processes of Rengat Dialeot}

The morphological processes of Rengat dialect consist of: 
a. Affixation which included prefixation, suffixation, and confixation. The three kinds of affixations found in this study were derived from roots of Rengat dialect itself in forming one word to become another one.

b. Reduplication which included complete reduplication, reduplication with the change of a phoneme, and reduplication with affixes. The three kinds of reduplications found in this study could be formed in such ways: (1) envolving roots of Rengat dialeot itself, (2) ohanging one of its phonemes which was attached to its own roots, and (3) adding prefixes and suffixes in its roots.

c. Compounding which included (1) Noun1 + Noun2, (2) Verb1 + Noun1, (3) Noun1 + Adjective, and (4) Adjeotive + Noun1. The four compoundings found in this study were also similar to the Indonesian, where the first part of the morpheme explained the second one.

(2) The Morphophonological Processes of Rengat Diaiect

The Morphophonological processes of Rengat dialect cunsist of :

a. Assimilation which included regressive assimilation, progressive assimilation, addition of a phoneme, and deletion of a phoneme. The four kinds of assimilation found in this study could be formed as follows: (1) a morpheme of Rengat dialect which were influenced by a sound infront of their invironment, and (2) certain phoneme which was added to certain roots whioh were dropped in forming affixation. b. Dissimilation which included substitutional process of a phoneme as follows: (1) certain phoneme in reduplication processes of Rengat dialect could change to become the other ones, and (2) certain roots of Rengat dialset ending in cortain vowels could be inserted by certain consonants in fcrming affixation.

\section{Suggestions}

This research cars be proposed as follows:

In this research can give contributivin: to the aspect of morphology of Rengat dialest in the regency of Inhu, Rian Province. This is caused by: first, Rengat dialect has never been investigated, therefore, the results found in this research can contribute to those who are interested in conducting research of other dialects in Riau Province, and second, no studies of Rengat dialeot, i.e, this research is the first step to describe the forms of morphology of Rengat dialect in the regency of Indragiri Hulu, Riau Province.

(1) Although this research only refers to the construction of morphological and morphophonological processes of Rengat dialect, its results, at least, can be considered as follows:

a. the development of local content curriculum at the Elementary level. In developing this curriculum, the decision makers of local content course curriculum of Department of Education and Culture of Indragiri Hulu Regency can also consider that in the Dialect of Rengat the phoneme/h/ only occurs in word final position. The suffix \{$k a n\}$ in the Indonesian becomes $\{-a n\}$ in the dialect of 
Rengat. Therefore teachers in Bahasa Indonesia and English should be aware of the students' difficulty in pronouncing $/ \mathrm{h} /$ in word initial position and pronounoing $/ \mathrm{k} /$ in final position in English.

b. the teachers of Bahasa Indonesia should also be aware of the students' difficulty in pronouncing the derivatives of nouns coming from adjective which involves the phoneme $\mathrm{lk} /$ in the process, such as loantI?/ becomes /k2cantikan/. The students in this case would tend to pronounce /kocanti?an/.

c. the results of this research can also be considered as inputs to develop the local and the Indonesian language.

(2) In developing of local content curriculum, the results of this research can also be considered as the teaching materials of local content course at the Elementary level. For example, (1) the forms of affixation, reduplioation, compounding, assimilation, and dissimilation of Rengat dialect whi refer the differences to the Indonesian can bs used as th teashing materiais, (2) tho morphemos of Rengat dialect which refer different pronounciations to the Indonesian can also be used as the teavhing materials, and (3) several phonemes of Rengat dialect which do not exist, and they have different sounds to the Indonesian and English can also be used as the teaching materials.

(3) Further research is also suggested, beyond the field of morphology, other fields like syntax and lexicon of Rengat dialect need also to be investigated, so that the sentences and vocabularies used in that dialect will be known about.
In other words, doing so, provides its characteristios which can differ from othor dialeots of, specifically Indragiri Huiu Regency, and generaliy, Riau Province.

Lastly, the investigator hopes that readers and further researchers of this researoh oan consider the above suggestions.

\section{REFERENCES}

Al-Qodi, nassir salah. 1392. The acquisition of English Derivational Morphology of Arat Speakers: Emperical testing. Languaga sciences. A World Journai of the Scicnces of languages. Vol. 14. 1/2 January/April. Now York: Pergamon Press.

Antilla, Raimo. 1972. An Introduction to Historical and Comparative Linguistics. New York: The Macmillan Company.

Badudu, J.S. 1992. Cakrowala Bahasa Indonesia II. Jakarta: PT Gramadia Pustaka Utama.

Bauer, Laurie. 1984. English Word-Frormation. Cambridge: Cambrige university Press.

Bogdan, Robert and Taylor J. Steven. 1975. Introduction to Qualitative Research Methods. Boston: John \& Sons, Inc.

Chaika, Elaine. 1982. Language: the Social Mirror. Row loy: newbury House Publisher. 
Dahlan, Saidat. 1983. Hubungan Bahasa dan Dialek Melayu Kabupaten Kampar Bagian Timur dengan Bahasa di Daerah bekas Kerajaan Siak. jakarta. Depdikbud RI

Dahlan, Saidat. 1991. Struktur Bahasa Melayu Riau Dialek Pesisir. Jakarta: Depdikbud RI..

De Hollander, J.J. 1384. Pedoman Bahasa dan Sastra Melayu. Jakarta: Balai Pustaka.

Froitzheins, Claudia. 1984. Language Varieties and Situation. A Journal Language in Society vol. 15, No. 4. Cambridge: Cambridge University Press.

Gleason, H.A. 1961. An Introduction to Descriptive Linguistics. New York: Henry Holt and Co.

Hamidy, U.U. 1386. Bahasa Melayu dan Kebudaycannya. Pekanbaru: UIR Press.

Jakamilena, Nico. 1979. Tapera Affixes a Dialect of Tanah Nierah Jaya Purc. Thesis IKIP Malang.

J. Eamarin, William. 1967. Field Linguistics. Now York: Holt, Rinehart and Winston, Inc.

Kraska, Iwona. 1992. Studies in Linguistic Sciences. Journal of the Lansuage Science of Linguistics. Vol.22.No.1. Department of Linguistios, University of Illonois.

Luther, Martin Manda. 1972. An Introduction to Toraja Morphology. Thesis IKIP, Malang.

Miller, J. 1985. Semantic and Syntax. Parallels and Connections. Cambridge: Cambridge University of Michigan Press.

Nida, E.A. 1946. Morphology. The Descriptive Analysis of Words. Ann Arbor: University of Michigan Press.

Parera, Jos Daniel. 1994. Morphology Behasa. Edisi Kedua. Jakarta: PT Gramedia Pustaka Utama.

Pleh, Csaba. 1990. An Interdiciplinary Journal of the Language Sciences (Linguistics).Vol.28. No. 6. London: Typeset.

Ramlan, M. 1980. Ilmu Bahasa Indonesia: Morphology. Yogyakarta: CV Kayo.

Ramat, Paulc. 1990. Ain Interdiciplinary Journal of the Language Sciances (Linguistics). Vol. 28. No. 6 London: Typeset.

Salimi, L. Gladipo. 1991. A elournal Language in Soviety. Vul. 22 No. 2. Cambridge: Cambridge University Fross.

Samsuri. 1985. Analisis Bahasa. Jakarta: Erlangga. 
Kridalaksana, Harimukti. 1984. Kamus Linguistik. Jakarta PT Gramedia.

Kuczaj, A. Stan and Borys, H. Robart. 1988. Th Overgeneraiization of Morphologioal forms as Function of Experiance. A World Jolimal of th Sciences of Langluags. Vol. 10. No. 1 Now York Pergamon Frgss Uxford.

Kudo. Takavuki. 1992. Word Formation in Aphasi Evidence from Japanese Kanji Words. Journal Newrolinguistics: An International Journal for th Study of Brain. Function in Language Behavior an Experience. New York: Pergamon Press Oxford

Laddicoat, A.J. 1989. An Interdiciplinary Journal of th Language Sciences (Linguistics). Vol.27. No The Netherland.

Lass, Ruger. 1991. Phonology. Cambridge: Cambrid University Press.

Labov. W. 1970. The Study of Language in Its Soc Context. J. Pride \& Holmes (eds), Sociolinguisti Harmonworth: Penguin.

Lehmann, Winfred P. 1983. Language: An Introduct Now York: Random House, Inc.

Stork, F.C., and Widdowson, J. D. A. 1994. Learning about Linguistics: An Introduction Workbook. London: The University of Chicago Press

Schano. A. Sanford. 1973. Generctive Phonology. San Diego: Prentice-Hall, Inc.

Sturtevant, E. H. 1973. Linguistic Change. An Introdusction to the Historical Study of Language. Chivago: The University of Chicago Press.

Suloiman, M. Saish. 1990. Lexical Conditioning of Phonological Variation. Language Sciences. A World Journal of the Sciences of Language. Vol. 12, No. 4. New York: Pergamon Press Oxford.

Tomori, S. H. Olu. 1977. The Morphology and Syntax of Present-day English. An Introduction. London: Adlard \& Son Ltd.

Trudgil, Peter and Chamber, J.K. 1991. Dialects of English Studies in Grammatical Variation. New York and London: Longman.

Vehaar, J. W. M. 1992. Pengantar Linguistik. Yogyakarta: Gajah Mada University Press.

Willis, J. Brenda. 1990. On the Orthographic Basis of Phonemic Segments in Linguistic Competence and Performance. Languagr Sciences: $A$ World Journal of the Sciences of Language. Vol.12, No.4. New York: Pergamon Press Oxford. 


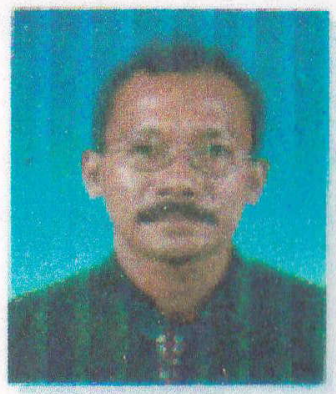

SENO H.PUTRA, Drs., M.Pd.,Ph,D, anak kedua dari H.M Boerhan Hatta (alm) dan Hj.Siti Ainah yang dilahirkan di Rongat Indra Giri Huiu poda tanggal 25 Agustus 1967. Strata satu diselesaikan pada FKIP UNRI (1991), Strata Dua diselesuiksn pada IKIP Malang (1997), dan Strata Tiga seicsaikan pada UKM Malaysia (2004). Adapun ketiga gelar tersebut diperoleh melalui beasiswa pendidikan

Direktur Grant's English Foundation Pekanbaru dun Rengat (1987-1995); Instruktur Bhs. Inggris, dibeberapa Kursus Bhs. Inggris di Pekanbaru (1987-1995); Instruktur B. Ingeris di Caltex (1989): Imigrasi Pekanbaru (1994-1995); AURI (1994); Instruktur Bhs.Inggris PEMDA Inhil (2000); Instruktur Bhs.Ingeris Sandi English, Instruktur Bhs.inggris Para guru sosiolinguistik FKIP, UIR (2001). Analisis Wacana dan Bahasa Koran (1998), Bahasa Melayu dan Penelitiannya (1998), Alumni FKIP Menjaring Peluang Kerja (2000), Linguistics Involment in Taching and Learning English (2001), Linguistik Hubungannya Dengan IPTEK (Orasi Ilmiah,Ultah UIR, 2004). Mutu Pendidikan (20016, Mutu Pendidikan dan Realisasinya di Masyarakat (2006), Bahasa dan Budaya Melayu Tua (2003), dil. Pemakalah, Nara Sumber RTV \&RRI, Artikel Ilmiah Populer di Media Massa (300 buah), Pencipta \& voc.Lagu-Lagu Melayu "Riau Melayu Berdendang"(2004-kini), Lagu-lagu Pop d

\section{ISBN $979-792-058-5$}

